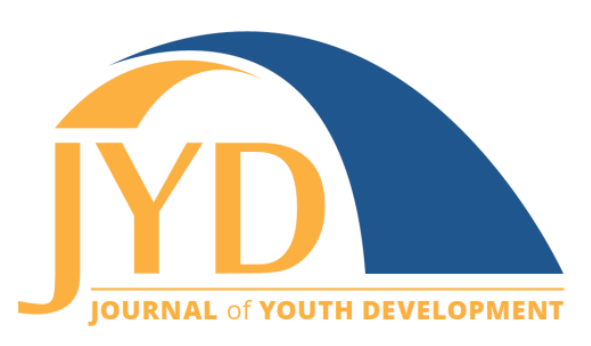

http://jyd.pitt.edu/ | Vol. 16 Issue 2-3 DOI 10.5195/jyd.2021.1048 | ISSN 2325-4017 (online)

\title{
Impact of an Empowerment and Employability Program for Adolescent Girls: Evidence From India
}

\section{Prerna Kumar}

International Center for Research on Women, Asia pkumar@icrw.org

\section{Amenla Nuken}

International Center for Research on Women, Asia bnuken@icrw.org

\section{Nitin Datta}

International Center for Research on Women, Asia ndatta@icrw.org

\author{
Aditi Vyas \\ International Center for Research on Women, Asia \\ avyas@icrw.org
}

\begin{abstract}
Existing research indicates that self-efficacy, aspirations, skills, and an enabling environment are essential for the economic empowerment of adolescent girls. In India, due to deeply rooted patriarchal views and social norms, adolescent girls face a range of social restrictions on their ability to make any decisions about their education or life choices. Plan-It Girls, a multi-level, multi-stakeholder program seeks to build adolescent girls' agency and promote gender equality to support their aspirations. It equips girls with a gender perspective, life skills, and employability skills to help them transition from school to work through a gender-integrated curriculum while also engaging with significant stakeholders to shift gender norms and create an enabling environment for girls to reach their potential. This evaluation employed a quasiexperimental longitudinal cohort design, with the objective of understanding the program's impact on the empowerment and employability of adolescent girls. The findings indicate that self-esteem and selfefficacy can be bolstered, and gender attitudes can be shifted in the short run with such a program. Though there were differences by age and program site, overall, the program was found to be effective in equipping girls with employability skills and preparing them for school-to-work transition. The program was impactful in empowering girls during adolescence when they had early exposure to the program. Adolescence is also when gender attitudes are deepening. As such, the program is considering more intentional focus on this age range in future programming efforts.
\end{abstract}

Key words: adolescent girls, empowerment, employability, self-esteem, self-efficacy, gender attitudes, economic self-efficacy, preparation to work, family support, impact evaluation 


\section{Introduction}

Program and policymakers are increasingly recognizing the value of investing in the positive development of youth by equipping them with the technical skills, education, and life skills (UNFPA \& Census of India, 2014; United Nations Department of Economic and Social Affairs, 2015) needed to thrive in their contexts. Investing in the positive development of youth not only has positive impacts on society and the economy, but it also enhances adolescents' ability to maintain good physical and mental health, avoid risky behaviors, recover from adversity, succeed in school or the workplace, and exercise leadership (Bonell et. al., 2016; Hameed \& Mehrotra, 2017; UNICEF, 2018).

Positive youth development (PYD) theory and programming recognizes the need to study the relations between the specific assets and contextual resources that support the healthy development of youth. The PYD framework defines four key domains of youth development: (a) assets, (b) agency, (c) contribution, and (d) a positive enabling environment. The framework recognizes that while it is critical for young people to have access to resources, skills and competencies, it is equally important that they have the agency to assess the "ability to employ their (youth) assets and aspirations to make or influence their own decisions about their lives and set their own goals, as well as to act upon those decisions in order to achieve desired outcomes" (Hinson et al., 2016).

Internationally, programs and policymakers are also increasingly taking a PYD perspective to serving the needs of diverse youth around the world, with special focus on girls and women. Youth development and gender equality are at the core of the commitments made by the sustainable development agenda (United Nations, 2018) that positions young people not as beneficiaries but as active contributors. The sustainable development goals (SDGs) highlight the need to address gender inequalities and disparities across all the goals and mainstream gender perspectives in the implementation of the agenda with additional focus on young people, especially vis-à-vis education and employment (United Nations, 2018). Within the PYD framework, workforce readiness and employability are intrinsic to building assets and agency (Alvarado et. al., 2017).

The PYD framework is useful for describing, explaining, and optimizing the relations between girls and their contexts and how those relations can lead to improved skills training, employability, and well-being. Programs focused on the positive development of adolescent girls living in the majority world need to integrate a gender lens and create an enabling ecosystem 


\section{Impact of an Empowerment and Employability Program}

that provides them with market linkages to create livelihood opportunities. These enabling ecosystems include programs that need to create safe spaces, with adult mentors, and must invest in adolescent girls' education and positive social-emotional skill development (Nanda et al., 2013).

In India, due to the deeply rooted patriarchal views, social norms, traditions, and social institutions that can result in unfortunate consequences for their social and economic outcomes (UNICEF \& Breakthrough, 2016), adolescent girls are often at a disadvantage in terms of access to PYD programming or impacts of policy. Girls tend to face a range of social risks and restrictions, including restricted mobility and limited or no involvement in decisions about their education or life choices. Adolescent girls are more vulnerable than their male counterparts to dropping out of school, early or forced marriage, and violence (Blum et al., 2017; Nanda et al., 2014; Pandita, 2015,). Whereas a study in Jharkhand by the World Bank found that almost all girls want to complete higher secondary education and 86 percent want to work for pay outside their homes, girls still have low secondary level school completion rates, and the gender gap in labor force participation is on the rise (Roy et al., 2018).

In addition, due to the deeply entrenched gender inequalities, the economic empowerment of women and girls in India is constrained by poor access to education and lack of opportunities for acquiring skills and connections that could facilitate productive entry into the labor market (Hunt \& Samman, 2016). Instead, women and girls make up the majority of work in the informal economy in India. This work is typically poorly paid, can be dangerous, and lacks both benefits and opportunities for advancement. Program and policy responses framed in PYD need to give girls the education and skills they need to obtain and retain quality employment (Verick, 2014).

The Plan-It Girls program framed in a PYD perspective, is a multi-level, multi-stakeholder program. It seeks to build agency of adolescent girls in India, promote gender equality, and support them in achieving their future aspirations for education and employment.

\section{Plan-It Girls: Empowerment and Employability for Adolescent Girls}

Plan-It Girls was designed as a multi-level, multi-stakeholder intervention aimed to build agency of adolescent girls in the age group of 14 to 17 years, to equip them with life skills and employability skills and to create an enabling environment. The program intended to create a pool of adolescent girls who had the life skills and employability skills to make the transition 


\section{Impact of an Empowerment and Employability Program}

from school to work. However, evidence suggests that while equipping girls with the requisite skills is necessary, it is not sufficient for this transition as gender inequities limit their choices and opportunities (Dalberg, 2020; World Bank, 2014). This implies that a program like Plan-It Girls must intervene not only with adolescent girls but with all the stakeholders who influence their choices and make decisions for them, thus creating an enabling environment.

As a gender-transformative program, Plan-It Girls postulated that a gender-integrated life skills and employability skills personal advancement curriculum for adolescent girls-P.A.C.E. for Adolescents curriculum ${ }^{1}$-will improve self-esteem and self-efficacy and foster gender-equitable attitudes, aspirations for being an economic entity, and greater involvement in decision making and seeking parental support. The curriculum has two key domains: Empowerment that includes two modules on self and self-efficacy and Employability that comprises two modules on resourcefulness and employability. The girls were also provided information and platforms to create linkages with locally available opportunities.

To support the self-transformation in girls and smooth school-to-work transition with an enabling environment, gender relations in family and school needed to be influenced along with structural changes in the community and institutions. This integrated approach of equipping the girls with life and employability skills, information about linkages, and an enabling environment was expected to improve the perception of girls about self, gender roles, gender division of work and family support, reflecting in their aspirations, and belief in their ability to pursue their dreams.

Plan-It Girls equips girls studying in Grades 9 and 11 with an understanding of self, gender, power, patriarchy, and its impact on their day-to-day lives, along with life skills and employability skills over a period of two academic years. The gender-integrated curriculum, which concludes with a career fair, is designed to help them transition from school to work. The program also engages with male peers, parents, teachers, and community members to shift gender norms and create an enabling environment for girls to reach their potential. Figure 1 shows the key program activities aimed at different stakeholder groups.

\footnotetext{
${ }^{1}$ The first draft of P.A.C.E. Curriculum for Older Adolescent Girls was developed by ICRW as part of an intervention research project "Planning Ahead for Girls Empowerment and Employability" (PAGE) supported by the MacArthur Foundation. The curriculum was revisited and reviewed through learning circles with youth facilitators. The curriculum was further adapted for Gap Inc.'s P.A.C.E. for Adolescents Curriculum by ICRW. ICRW is a licensed partner of Gap Inc. and used the curriculum as part of Plan-It Girls program.
} 
Figure 1: Key Program Activities for the Stakeholders

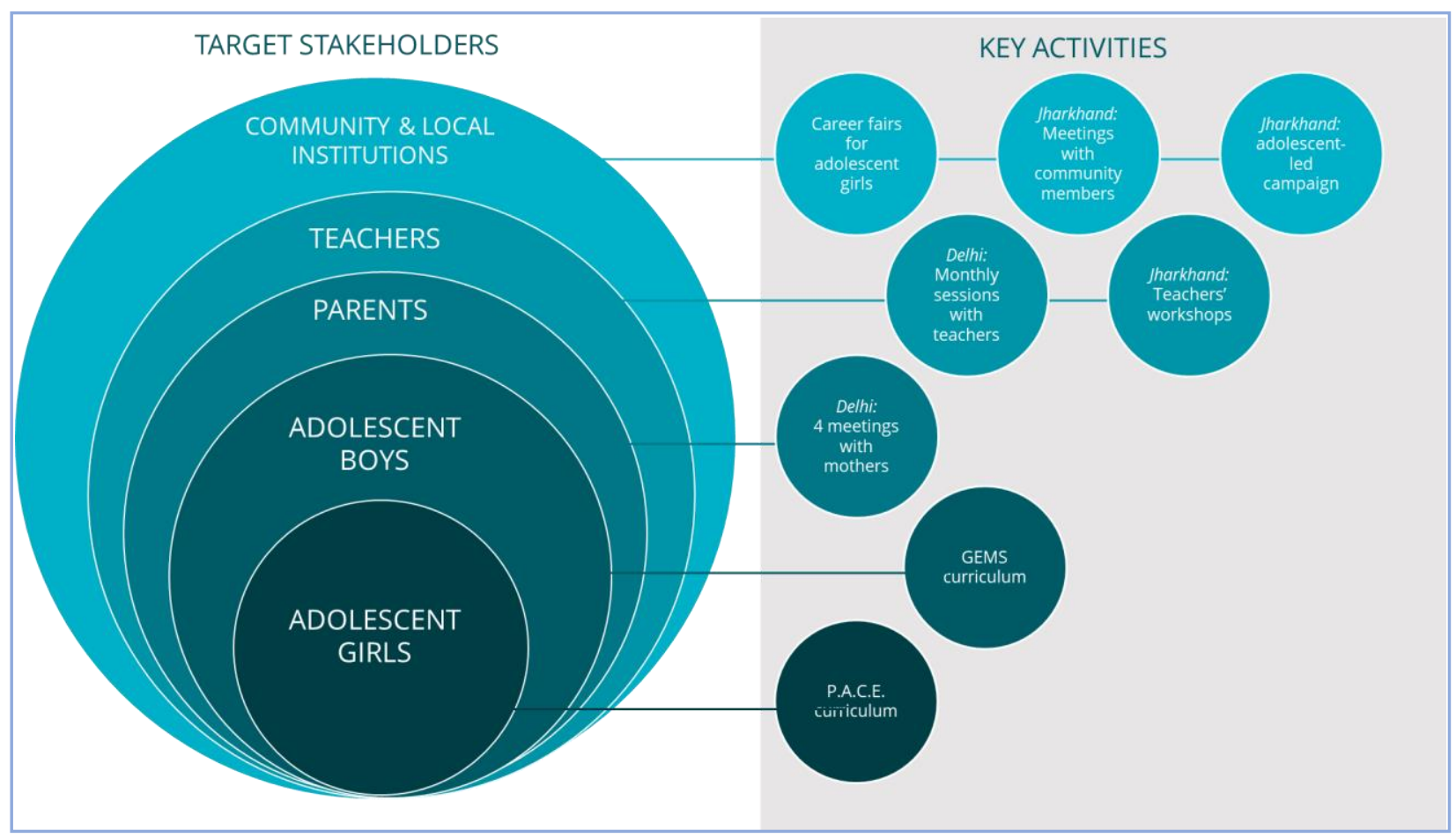

The program was implemented by an international NGO, Restless Development and an Indian NGO, Pravah in 10 government girls' senior secondary (GGSS) schools from Education Zone 29 of the Southeast Delhi district ${ }^{2}$ and in 10 co-educational government senior secondary schools in Deoghar and Pakur, Jharkhand. The diversity of these sites allowed for testing the model in both an urban and a rural setting.

ICRW conducted an impact evaluation study to assess the impact of the Plan-It Girls program, both in Delhi and Jharkhand. A younger cohort of girls in Grade 9 who were followed through Grade 10, along with an older cohort of girls from Grade 11 followed through Grade 12, were enrolled for the impact evaluation study using quantitative methods. Since the study intended to understand the impact of the program on adolescent girls, it comprised a baseline and an endline survey for which girls were enrolled from program intervention schools as well as comparison schools. The impact evaluation study was conducted to answer the following research questions:

\footnotetext{
${ }^{2}$ In Delhi, Government senior secondary schools (GSSS) with double shifts (where girls study in the morning shift (GGSSS) and boys study in the afternoon shift (GBSSS) in the same schools) were included in the study. The GEMS curriculum was implemented for the boys in the afternoon shift. Gender Equity Movement in Schools (GEMS) curriculum was developed to prevent violence and promote gender equity in schools.
} 
1. What is the impact of the intervention on girls' self-efficacy and gender equitable attitudes in an urban and a rural setting?

2. Was the intervention successful in creating a pool of girls who have the life skills and employability skills and believe in their ability to transition from school to work?

3. Do girls perceive that their communities and schools are supportive of their choices?

While the broader impact evaluation focused on assessing the effectiveness of the program on a broad range of key PYD indicators, ${ }^{3}$ this paper focuses on understanding the impact of the program on selected PYD indicators including empowerment (viz self-esteem, self-efficacy, and positive gender attitudes) and employability (viz career decision-making efficacy, economic selfefficacy, and preparation to work in the future). The systematic review of PYD (Alvarado et al., 2017) establishes that most programs aimed at improving work readiness and employability outcomes also improve youth assets that include soft skills along with the enabling environment rather than focusing only on vocational skills. This study will also help in addressing the evidence gap that the review highlighted vis-à-vis effectiveness of programs focusing on employability.

\section{Data and Methods}

The evaluation employed a quasi-experimental longitudinal cohort design, following two cohorts of girls from Grades 9 through 10 and from Grades 11 through 12 in both urban Delhi and rural Jharkhand.

In urban Delhi, as permitted by the Department of Education, Government of Delhi, a total of 19 government girls senior secondary schools (GGSSS) were selected, including 10 intervention schools from Southeast Delhi and nine comparison schools from Southwest Delhi. From the list of all girls aged 14 to 20 years in grades 9 and 11 of all intervention schools, 100 girls from each of the grades ( 9 and 11) were selected for the baseline survey using systematic random sampling. In the comparison schools of Delhi, where the enrollment number in each grade was below the required sample, all available girls were enrolled for the baseline survey. In rural Jharkhand, a total of 20 co-educational government schools were randomly selected from the two districts of Deoghar and Pakur; 10 intervention and 10 comparison schools. All girls aged

\footnotetext{
${ }^{3}$ Key outcome indicators for the evaluation are self-esteem, self-efficacy, self-assertive efficacy, gender equitable attitudes, mobility alone, decision making by self, career decision-making efficacy, economic self-efficacy, preparation to work in future, school climate, family support, number of safe spaces, perceived family support for education and work, enlisting family support for education and work, perceived teacher support for education and work, enlisting teacher support for education and work, perceived peer support for education and work.
} 


\section{Impact of an Empowerment and Employability Program}

14 to 20 years enrolled in grades 9 and 11 of the selected schools were recruited for the baseline survey.

The baseline survey was conducted between October 2017 and February 2018 before the implementation of the program when the girls were in Grade 9 or Grade 11. After completion of the program intervention, the same cohort of girls was surveyed. The endline survey was conducted from November 2018 to January 2019.

Table 1 shows the sample distribution by grade and by geographical region (program site) of the number of girls who were interviewed at baseline and endline for both the program participants and the comparison group. At baseline, a total of 3,434 girls were interviewed in Delhi and 2,971 in Jharkhand. In Delhi, 82\% of the girls interviewed at baseline were interviewed again at endline and in Jharkhand $97 \%$ of the baseline respondents were interviewed again at endline. For this paper, analysis is based on pure cohort samples including only those girls who were interviewed both at baseline and endline. In Delhi, this comprises a total sample size of 1,176 girls in Grade 9 and 1,646 girls in Grade 11, while in Jharkhand this is a total of 1,831 girls in Grade 9 and 1,038 girls in Grade 11 .

In this paper, a longitudinal mixed model using balanced panel data has been used as the primary approach to estimate the impact of the program using the difference-in-difference (DID) method. For DID analysis, girls who participated in both the rounds of baseline and endline surveys were considered as the analytical sample. The DID approach removes biases in post-intervention period comparisons between the intervention and comparison group which could result from differences between these two groups, as well as biases from comparisons over time in the intervention and comparison group as a result of differential attrition or other causes of the outcome. This differential attrition could lead to bias in the analytical sampling. The bias was corrected using advanced statistical techniques like panel double-differencing adjusting for background characteristics and school level clustering. We also estimated Lee bounds on the treatment effects (D. Lee, 2009) to account for bias due to differential attrition and for the possibility that attrition is endogenous to treatment. 
Table 1. Analytical Sample: Girls Who Were Interviewed at Both Baseline and Endline

\begin{tabular}{|c|c|c|c|c|c|c|c|c|}
\hline \multicolumn{9}{|c|}{ Grade 9} \\
\hline & \multicolumn{4}{|c|}{ Delhi } & \multicolumn{4}{|c|}{ Jharkhand } \\
\hline School type & Baseline & Endline & $\begin{array}{l}\text { Endline } \\
\text { response } \\
\text { rate (\%) }\end{array}$ & $\begin{array}{c}\text { Analytical } \\
\text { sample - } \\
\text { Pure cohort }\end{array}$ & Baseline & Endline & $\begin{array}{l}\text { Endline } \\
\text { response } \\
\text { rate (\%) }\end{array}$ & $\begin{array}{l}\text { Analytical } \\
\text { sample - } \\
\text { Pure cohort }\end{array}$ \\
\hline Intervention & 748 & 530 & 70.9 & 530 & 853 & 823 & 96.5 & 823 \\
\hline Comparison & 804 & 646 & 80.3 & 646 & 1031 & 1008 & 97.8 & 1008 \\
\hline Total & 1552 & 1176 & 75.8 & 1176 & 1884 & 1831 & 97.2 & 1831 \\
\hline \multicolumn{9}{|c|}{ Grade 11} \\
\hline & \multicolumn{4}{|c|}{ Delhi } & \multicolumn{4}{|c|}{ Jharkhand } \\
\hline School type & Baseline & Endline & $\begin{array}{l}\text { Endline } \\
\text { response } \\
\text { rate }(\%)\end{array}$ & $\begin{array}{l}\text { Analytical } \\
\text { sample - } \\
\text { Pure cohort }\end{array}$ & Baseline & Endline & $\begin{array}{l}\text { Endline } \\
\text { response } \\
\text { rate }(\%)\end{array}$ & $\begin{array}{c}\text { Analytical } \\
\text { sample - } \\
\text { Pure cohort }\end{array}$ \\
\hline Intervention & 796 & 700 & 87.9 & 693 & 555 & 526 & 94.8 & 526 \\
\hline Comparison & 1086 & 957 & 88.1 & 953 & 532 & 512 & 96.2 & 512 \\
\hline Total & 1882 & 1657 & 88.0 & 1646 & 1087 & 1038 & 95.5 & 1038 \\
\hline
\end{tabular}

\section{Ethical Considerations}

The study protocol was reviewed and approved by ICRW's Institutional Review Board with an additional local approval by Sigma-IRB. Informed consent was obtained from all participants and their guardians after explaining the purpose of the study. Participants were informed about their rights to refuse participation and/or withdraw their consent at any time.

\section{Measures}

Empowerment and employability were measured using the constructs listed in Table 2. The constructs were identified by USAID's YouthPower Learning as key constructs that promote empowerment and employability in PYD programs around the world (Hinson et al., 2016). The empowerment indicators included measures of girls' own self-perception viz self-esteem (their overall sense of self-worth), self-efficacy (belief in one's ability to succeed in specific situations or accomplish a task), and gender-equitable attitudes (including gender roles, gender attributes and gender-based violence). The employability indicators included career decision-making efficacy (an individual's degree of belief that they can successfully complete tasks necessary to 
making significant career decisions), economic self-efficacy (individual's perceived ability to perform economic or financial tasks) and preparation for work in the future (preparatory steps undertaken toward future goals such as seeking relevant information for future employment, training opportunities and preparing a resume). The empowerment and employability indicators used in the study were a mix of standardized scales (validated globally) and composite indices that were constructed based on the questions asked in the study tool, which was pretested for feasibility and applicability before implementing the survey. All the scales were tested for reliability and the Cronbach's alpha values were greater than .7 .

Table 2. Operational Definitions of Empowerment and Employability Indicators

\begin{tabular}{|c|c|c|}
\hline Self-esteem & $\begin{array}{c}10 \\
\text { items }\end{array}$ & $\begin{array}{l}\text { Self-esteem scale (Rosenberg,1965). The self-esteem scale consists of } 10 \text { items to } \\
\text { understand adolescent girls' favorable or unfavorable attitude towards the self. The } \\
\text { scale reflects an individual's overall subjective emotional evaluation of their own } \\
\text { worth/value. The items were scored on a 4-point scale from } 0 \text { (strongly disagree) to } 3 \\
\text { (strongly agree). Summative scores for all ten items range from } 0 \text { to } 30 \text {. }\end{array}$ \\
\hline Self & $\begin{array}{c}10 \\
\text { items }\end{array}$ & $\begin{array}{l}\text { Self-efficacy scale (Schwarzer \& Jerusalem,1995). A ten-item global measure of self- } \\
\text { efficacy, the General Self-Efficacy Scale (GSES) measures optimistic self-beliefs in one's } \\
\text { ability to cope with difficult tasks, demands or adversity and achieve objectives. The } \\
\text { items were scored on a 4-point scale: } 1 \text { (not at all true), } 2 \text { (hardly true), } 3 \text { (moderately } \\
\text { true) and } 4 \text { (exactly true). Responses to all ten items yield a final composite score with } \\
\text { a range from } 10 \text { to } 40 .\end{array}$ \\
\hline $\begin{array}{l}\text { Gender-equitable } \\
\text { attitudes }\end{array}$ & $\begin{array}{c}20 \\
\text { items }\end{array}$ & $\begin{array}{l}\text { The gender attitude scale measures attitudes towards gender norms and differing } \\
\text { social expectations for men and women and includes statements on gender roles and } \\
\text { responsibilities, gender attributes and gender-based violence. The 20-item scale from } \\
\text { Gender Equity Movement in Schools (GEMS)-ICRW Jharkhand study (Achyut, 2016) } \\
\text { scored on a 4-point Likert scale from } 1 \text { (strongly agree) to } 4 \text { (strongly disagree), } \\
\text { summative over items. The responses supporting equitable norms received the highest } \\
\text { score of 4, while that of inequitable received } 1 \text {. The final composite score ranged from } \\
20 \text { to } 80 \text {. }\end{array}$ \\
\hline $\begin{array}{l}\text { Career decision- } \\
\text { making efficacy }\end{array}$ & $\begin{array}{c}11 \\
\text { items }\end{array}$ & $\begin{array}{l}\text { Career decision-making self-efficacy scale (Betz \& Luzzo, 1996) uses a Likert 5-point } \\
\text { scale from } 1 \text { (no confidence) to } 5 \text { (complete confidence). This scale depicts an } \\
\text { individual's belief in their ability to make career decisions. Girls were asked to rate their } \\
\text { confidence on this } 5 \text {-point scale for } 11 \text { statements related to their ability to seek } \\
\text { information and take steps to make career decisions. The summative score ranged } \\
\text { from } 11 \text { to } 55 \text {. }\end{array}$ \\
\hline
\end{tabular}


Table 2. (continued)

\begin{tabular}{|c|c|c|}
\hline $\begin{array}{l}\text { Economic self- } \\
\text { efficacy }\end{array}$ & 3 items & $\begin{array}{l}\text { Economic self-efficacy scale (J. C. Lee \& Mortimer (2009) uses a Likert scale from } 1 \\
\text { (very low) to } 4 \text { (very high) measured by the student's perception of the certainty that } \\
\text { she, in adulthood, will: (a) own a home, (b) have a job that pays well, and (c) have a } \\
\text { job that she enjoys. This three-item measure was posed to girls who wanted to work } \\
\text { outside their homes and earn money in the future. If the girl did not want to work, a } \\
\text { score of zero was given so that those girls were not excluded in the analysis; this made } \\
\text { the scale a 5-point scale ranging from } 0 \text { to } 4 \text { and the overall score ranged from } 0 \text { to15. }\end{array}$ \\
\hline $\begin{array}{l}\text { Preparation to } \\
\text { work in future }\end{array}$ & 8 items & $\begin{array}{l}\text { Girls were asked whether they have or plan to undertake any preparation related to the } \\
\text { kind of work they want to do in the future, such as pursuing higher education, seeking } \\
\text { information for work, exposure visits, completing skill courses, internships, seeking } \\
\text { relevant information for future employment, developing a CV, etc. A score value of } 1 \\
\text { was given if girls agreed to (had done or planned to do) these activities, otherwise a } \\
\text { score value of } 0 \text { was given. The overall score ranged from } 0 \text { to } 8 \text {. }\end{array}$ \\
\hline School climate & $\begin{array}{c}16 \\
\text { items }\end{array}$ & $\begin{array}{l}\text { To understand girls' perception of school climate, girls were asked to think and respond } \\
\text { on whether they 'agree', 'somewhat agree' or 'do not agree' to questions related to } \\
\text { personal beliefs about going to school, relationships with teachers, relationships with } \\
\text { peers, teaching and learning practices in school, etc. A total of } 16 \text { items/questions were } \\
\text { used to measure school climate. A response supporting equitable/positive school } \\
\text { climate received the highest score of } 3 \text {, while that of inequitable/negative received } 1 \text {. } \\
\text { The overall range for school climate was } 16 \text { to } 48 \text {. }\end{array}$ \\
\hline Family support & 7 items & $\begin{array}{l}\text { Girls were asked } 7 \text { items/questions to gauge how much support they received from } \\
\text { family. The questions were related to studying at home regularly, studying during } \\
\text { exams, seeking information for higher education, seeking information for pursuing } \\
\text { career/work in future, learning things they are interested in, support in making } \\
\text { decisions or response to request for assistance/advice. A score value of } 1 \text { was given if } \\
\text { girls responded receiving support, otherwise a score value of } 0 \text { was given. The overall } \\
\text { range was } 0 \text { to } 7 \text {. }\end{array}$ \\
\hline
\end{tabular}

\section{Data Analysis}

The data from the baseline and endline surveys of girls from intervention and comparison schools was merged and analyzed using Stata 15.0 software. The mean scores of key empowerment and employability indicators were compared, without taking into account control variables, between the intervention and comparison groups at baseline and endline using 
difference-in-differences (DID) analysis. However, assessing the program impact by comparing the two groups without controlling for the variation in background characteristics at the baseline could lead to bias in interpretation of findings.

Thus, to assess the impact of the Plan-It Girls program on girls' empowerment and employability, a panel regression mixed model or the double difference (DID) regression analysis was conducted, controlling for several baseline characteristics for the girl at the individual and household level and also adjusted for school level clustering. The baseline variables used as controls were the girl's age, caste group, religion, father's education, mother's education, father's occupation, mother's occupation, number of siblings, having at least one brother, and wealth tertiles with school-level clustering. This analytical approach is a combination of before-after program and also treatment-control group comparisons and the double differencing accounts for the initial baseline differences in treatment and control groups.

The effect size of the program impact was calculated using standardized mean differences and Cohen's $d$ statistics where the thumb rule is to consider the following effect size thresholds: small (0.20), medium (0.50), large (0.80) and very large (1.30). Usually, the minimum relevant program impact is benchmarked at 0.30 . While in some cases the observed effect size may appear small, the significance of the indicator and its practical value should be also considered (Durlak, 2009) based on prior relevant research to provide some indication of the magnitude obtained in previous studies.

\section{Results}

As mentioned earlier, the variations in the background characteristics were found to be significant at the baseline. The analytical sample in Delhi from the intervention group was found to be significantly different from the comparison group on various background characteristics such as religion, caste, parents' education and occupation and the wealth strata. In Jharkhand, the two groups were found to be similar on most background characteristics, except caste where the difference was found to be significant at five percent. These characteristics are critical to the girls' agency and aspirations as it determines their access to education and skills and their social capital (Allendorf, 2012; World Bank, 2014). Therefore, the multivariate analysis controls for these differences to assess the impact of the program on both empowerment and employability of the girls. The significant results from the multivariate analysis are reported in the following section. 


\section{Impact of an Empowerment and Employability Program}

\section{Empowerment and Employability Outcomes Over Time}

Tables 3 and 4 provide the baseline and endline mean scores by study groups-intervention and comparison-among the analytical sample in Delhi (Table 3) and Jharkhand (Table 4) for three attributes of empowerment viz self-esteem, self-efficacy, and gender-equitable attitudes as well as employability attributes, which include career decision-making efficacy, economic selfefficacy, and preparation for work in future.

In Delhi, the Grade 9 girls who participated in Plan-It Girls scored an average self-esteem score of 18.2 , within a potential range of 0 to 30 . The self-esteem level increased over time as girls in the intervention schools scored an average score of 19.2 at endline. Similarly, among the Grade 11 girls in intervention schools of Delhi, the self-esteem level increased slightly over time from an average score of 18.9 at baseline to 19.5 at endline. Across both cohorts in Delhi, gender attitudes improved over time for girls in the intervention school.

In Jharkhand, across both cohorts, gender attitudes improved over time for girls in the intervention schools. Among Grade 9 girls, the average gender attitude score improved over time from an average score of 51.9 at baseline to 57.4 at endline. Among the Grade 11 girls, gender attitude improved over time, from an average score of 54.6 at baseline to 59.6 at endline. Their career decision-making efficacy and economic self-efficacy also seemed to improve slightly over time. However, the shift does not seem significant after controlling for all socio-economic characteristics. 
Impact of an Empowerment and Employability Program

Table 3. Mean Scores of Empowerment and Employability Outcome Variables Over Time Across Comparison and Intervention Schools and DID in Delhi

\begin{tabular}{|c|c|c|c|c|c|c|c|c|c|c|}
\hline & \multicolumn{5}{|c|}{ Delhi Grade-9 pure cohort } & \multicolumn{5}{|c|}{ Delhi Grade-11 pure cohort } \\
\hline & \multicolumn{2}{|c|}{ Intervention } & \multicolumn{2}{|c|}{ Comparison } & \multirow{2}{*}{$\begin{array}{l}\text { UNADJ } \\
\text { DID }\end{array}$} & \multicolumn{2}{|c|}{ Intervention } & \multicolumn{2}{|c|}{ Comparison } & \multirow{2}{*}{$\begin{array}{l}\text { UNADJ } \\
\text { DID }\end{array}$} \\
\hline & Baseline & Endline & Baseline & Endline & & Baseline & Endline & Baseline & Endline & \\
\hline Self-esteem & 18.2 & 19.2 & 19.7 & 19.2 & $1.6^{* * *}$ & 18.9 & 19.5 & 20.1 & 19.3 & $1.3^{* * *}$ \\
\hline Self-efficacy & 32.0 & 31.6 & 32.5 & 31.4 & 0.6 & 32.2 & 31.9 & 32.9 & 32.3 & 0.3 \\
\hline Gender attitudes & 58.1 & 61.7 & 61.2 & 59.4 & $5.4 * * *$ & 60.2 & 61.6 & 62.1 & 60.6 & $2.9 * * *$ \\
\hline $\begin{array}{l}\text { Career decision- } \\
\text { making efficacy }\end{array}$ & 39.1 & 39.7 & 38.5 & 39.6 & -0.5 & 39.6 & 40.4 & 40.3 & 41.6 & -0.4 \\
\hline Economic self-efficacy & 7.8 & 7.7 & 8.7 & 7.0 & $1.6 * * *$ & 9.0 & 8.2 & 9.2 & 8.2 & 0.3 \\
\hline $\begin{array}{l}\text { Preparation to work } \\
\text { in future }\end{array}$ & 5.2 & 4.4 & 6.1 & 3.7 & $1.6^{* * *}$ & 6.2 & 4.6 & 6.5 & 4.4 & $0.5^{* * *}$ \\
\hline School climate & 42.0 & 40.1 & 42.9 & 40.7 & 0.3 & 42.0 & 40.0 & 42.9 & 40.8 & 0.2 \\
\hline Family support & 6.8 & 6.9 & 6.9 & 6.8 & $0.2 * * *$ & 6.9 & 6.9 & 6.9 & 6.8 & $0.1^{* *}$ \\
\hline
\end{tabular}

Note. UNADJ DID: Unadjusted difference in differences

*** $p<.01, * * p<.05, * p<.1$ 
Impact of an Empowerment and Employability Program

Table 4. Mean Scores of Empowerment and Employability Outcome Variables Over Time Across Comparison and Intervention Schools and DID in Jharkhand

\begin{tabular}{|c|c|c|c|c|c|c|c|c|c|c|}
\hline & \multicolumn{5}{|c|}{ Jharkhand Grade-9 pure cohort } & \multicolumn{5}{|c|}{ Jharkhand Grade-11 pure cohort } \\
\hline & \multicolumn{2}{|c|}{ Intervention } & \multicolumn{2}{|c|}{ Comparison } & \multirow{2}{*}{$\begin{array}{l}\text { UNADJ } \\
\text { DID }\end{array}$} & \multicolumn{2}{|c|}{ Intervention } & \multicolumn{2}{|c|}{ Comparison } & \multirow{2}{*}{$\begin{array}{l}\text { UNADJ } \\
\text { DID }\end{array}$} \\
\hline & Baseline & Endline & Baseline & Endline & & Baseline & Endline & Baseline & Endline & \\
\hline Self-esteem & 18.9 & 19.6 & 19.1 & 18.7 & $1.1 * * *$ & 20.0 & 19.7 & 19.6 & 19.1 & 0.1 \\
\hline Self-efficacy & 30.2 & 29.5 & 31.8 & 29.4 & $1.7 * * *$ & 32.2 & 30.9 & 33.0 & 30.2 & $1.5^{* * *}$ \\
\hline Gender attitudes & 51.9 & 57.4 & 50.4 & 55.7 & 0.1 & 54.6 & 59.6 & 54.1 & 57.6 & $1.5^{* *}$ \\
\hline $\begin{array}{l}\text { Career decision- } \\
\text { making efficacy }\end{array}$ & 33.1 & 33.4 & 35.7 & 33.6 & $2.3^{* * *}$ & 36.8 & 37.3 & 37.7 & 35.4 & $2.7^{* * *}$ \\
\hline Economic self-efficacy & 4.3 & 5.4 & 4.5 & 5.3 & 0.3 & 5.8 & 6.9 & 5.5 & 6.9 & -0.4 \\
\hline $\begin{array}{l}\text { Preparation to work } \\
\text { in future }\end{array}$ & 3.2 & 2.8 & 3.1 & 2.7 & -0.1 & 4.2 & 3.8 & 3.8 & 3.7 & -0.3 \\
\hline School climate & 39.7 & 38.7 & 40.2 & 37.9 & $1.3 * * *$ & 40.6 & 39.5 & 40.3 & 37.8 & $1.4 * * *$ \\
\hline Family support & 6.7 & 6.5 & 6.7 & 6.5 & 0.0 & 6.8 & 6.7 & 6.9 & 6.6 & $0.2^{*}$ \\
\hline
\end{tabular}

Note. UNADJ DID: Unadjusted difference in differences

$* * * p<.01, * * p<.05, * p<.1$ 


\section{Program Impact and Effect Size on Empowerment and Employability Indicators}

The program impact (adjusted DID) on empowerment and employability of girls in Delhi and Jharkhand is presented in Table 5.

Table 5. Program Impact (Adjusted DID) in Empowerment and Employability Indicators in Delhi and Jharkhand

\begin{tabular}{|c|c|c|c|c|c|}
\hline & & \multicolumn{2}{|c|}{ Delhi } & \multicolumn{2}{|c|}{ Jharkhand } \\
\hline & & Grade 9 & Grade 11 & Grade 9 & Grade 11 \\
\hline Domains & Indicators & $\begin{array}{c}\text { Adjusted } \\
\text { DID }^{a}\end{array}$ & $\begin{array}{c}\text { Adjusted } \\
\text { DID a }\end{array}$ & $\begin{array}{c}\text { Adjusted } \\
\text { DID a }\end{array}$ & $\begin{array}{c}\text { Adjusted } \\
\text { DID }^{a}\end{array}$ \\
\hline \multirow{3}{*}{ Empowerment } & Self-esteem & $1.552 * * * \mathrm{~b}$ & $1.315^{* * \mathrm{~b}}$ & $1.118^{*}$ & 0.166 \\
\hline & Self-efficacy & 0.413 & -0.153 & $1.726 * *$ & $1.467 *$ \\
\hline & Gender attitudes & $4.585^{* *} \mathrm{~b}$ & $2.733 * \mathrm{~b}$ & 0.188 & 1.819 \\
\hline \multirow{3}{*}{ Employability } & Career decision-making efficacy & -0.594 & -0.902 & 2.342 & $2.764 *$ \\
\hline & Economic self-efficacy & $1.288^{* *}$ & 0.257 & 0.298 & -0.350 \\
\hline & Preparation to work in future & $1.366 * * * \mathrm{~b}$ & 0.561 & -0.054 & -0.283 \\
\hline \multirow{2}{*}{$\begin{array}{l}\text { Enabling } \\
\text { environment }\end{array}$} & Family support & $0.171^{* *}$ & $0.087 * *$ & & \\
\hline & School climate & & & & $1.437 *$ \\
\hline \multicolumn{2}{|l|}{ Total (M) } & 1176 & 1646 & 1831 & 1038 \\
\hline
\end{tabular}

Note. Adjusted DID: controlled for key socio-demographic characteristics at baseline such as girl's age, caste, religion, father's education, mother's education, father's occupation, mother's occupation, number of siblings, having a male sibling, and wealth tertiles.

a Impact coefficient $=$ school-type\#round-year

b Standardized mean difference/Cohen's d statistics, showing minimum relevant program impact is benchmarked at 0.30 . The effect size thresholds are small (0.20), medium (0.50), large (0.80) and very large (1.30).

$* * * p<.01, * * p<.05, * p<.1$

\section{Program Impact in Delhi}

In Delhi, it was found that the program impacted self-esteem and gender attitudes significantly but did not significantly impact self-efficacy across both Grade 9 and 11 cohorts. Among the girls who participated in the program intervention, mean self-esteem scores increased by 0.35 standard deviation 
$(S D)$ and mean gender attitude scores increased by $0.45 S D$ for Grade 9 girls, while among Grade 11 girls, mean self-esteem increased by $0.30 S D$ and mean gender attitude increased by $0.29 S D$.

Also, significant impact was observed on key employability outcome indicators-economic self-efficacy and preparation to work in the future-among the younger cohort girls in Delhi. Among Grade 9 girls who participated in the program intervention, mean economic self-efficacy increased by $0.19 S D$ and mean preparation to work increased by $0.34 \mathrm{SD}$. However, the program did not significantly impact these indicators for older cohort girls. In Delhi, program impact on perceived family support was significant for girls of both grades; the mean increased by $0.21 S D$ and $0.11 S D$, respectively.

\section{Program Impact in Jharkhand}

In the rural program site of Jharkhand, among the Grade 9 cohort, the program significantly impacted self-efficacy and self-esteem, although the effect size was found to be small. An increase in mean selfefficacy of $0.22 S D$ and in mean self-esteem of $0.23 S D$ was observed among girls who participated in the intervention. The program had a significant positive impact on self-efficacy of Grade 11 girls; mean self-efficacy increased by $0.21 S D$, which is considered a "small" effect. The program did not show a significant impact on gender attitudes of girls in Jharkhand.

Regarding employability skills, in Jharkhand, the program had a significant impact on decision-making efficacy of Grade 11 cohort girls; the mean of that indicator increased by 0.24 SD. However, no significant shift was observed among the younger cohort. The mean school climate improved significantly in Jharkhand by 0.24 for the younger cohort and .26 for the older cohort.

\section{Discussion}

The Plan-It Girls program had a significant impact on girls' self-perception across both urban and rural program sites. The findings establish that the program had a positive impact on self-esteem across Delhi's younger and older cohorts and among Jharkhand's younger cohort. It was only among the older cohort in Jharkhand, that the program did not have a significant positive impact on self-esteem.

While the effect size is small, the significant impact of Plan-It Girls on self-esteem is critical. A study by Yingling (2019) on the impact of music intervention on the Rosenberg self-esteem scale demonstrated only a small effect size. Robins et al. (2001) analyzed the construct validity of two global self-esteem measures including the Rosenberg scale. The four studies that the authors analyzed found the effect size 
to be between 0.2 to 0.7. Franck et al. (2008) also found the effect size of Cohen $d=0.25$ while analyzing the Rosenberg self-esteem scale. Hence, it could be argued that while the effect size may seem small, the significant impact of Plan-It Girls on self-esteem is critical.

The program was also found to have significant positive impact on gender attitudes among both Grades 9 and 11 of Delhi. The effect size ranged from 0.29 to 0.45 (grades 11 and 9 respectively), thus establishing that the program had a moderate impact on gender attitudes of girls in Delhi. This is in line with findings from another impact evaluation of a school-based gender attitude change program in India that found that the gender attitudes improved by 0.25 SD among adolescent boys and girls (Dhar et al., 2018).

In Delhi, significant positive impact on family support was observed. Family support included support related to studying at home regularly, studying during exams, seeking information for higher education, seeking information for pursuing career/work in future, learning things they are interested in, support in making decisions or response to request for assistance/advice. In Delhi, the program strategy focused on working with mothers of girls and supported mother-daughter conversations around girls' aspirations. The positive impact on improved family support can thus be attributed to focused engagement with mothers. Literature suggests that parental support impacts academic performance and self-concept (Chohan \& Khan, 2010; Lara \& Saracostti, 2019). This reinforces the criticality of family support as part of the adolescent girls' programming.

In Jharkhand, school climate was one of the indicators that was significantly positively impacted but showed only a small effect size across Grades 9 and 11 . Positive impact implies that the program was able to influence the school climate scale that included personal beliefs about going to school, relationships with teachers, relationships with peers, and teaching and learning practices in school. The positive change in perception about the school reflects that the intervention with boys and teachers in the co-educational schools of Jharkhand was able to create a safe space for girls. A meta-analysis by Dulay and Karadağ (2017) found medium effect size of school climate $(r=38.8)$ on student achievement. While the Plan-It Girls program had small effect, it is important to remember that in rural locations, an enabling environment in school could provide a safe space for socialization as well as realization of aspirations for adolescent girls.

The findings in terms of enhanced self-esteem, self-efficacy, shift in gender attitude and improvement in employability are encouraging. The findings highlight that self-esteem and self-efficacy can be bolstered and gender attitudes can be shifted in the short run with a multi-level and multi-stakeholder gender- 


\section{Impact of an Empowerment and Employability Program}

integrated life skills and employability skills program for girls. In urban Delhi, the significant shift in gender attitudes confirms that despite continuing gender expectations and roles, greater exposure and access to opportunities and resources in urban areas provides greater opportunity to contest gender norms unlike in rural areas (Saravanakumar \& Varakumari, 2019; Walker et al., 2012).

The significant and relevant impact in both empowerment and employability outcomes of younger cohort girls (Grade 9) in Delhi indicates that the program is more impactful in empowering girls and preparing them for an economic role when they are in their early adolescence and have greater exposure owing to their urban location. This could indicate that early adolescence is a better window of opportunity for intervention among urban adolescent girls. Construction of gender attitudes or individual perceptions about gender norms begin to form and are still malleable during early adolescence. Addressing gender equality and bringing to the fore gender discrimination precisely at the time when their gender attitudes are beginning to form, therefore, has the potential to alter their short and long-term gender attitudes (Blum et al., 2017; Yu et al., 2017).

While it is generally recognized that adolescence is a period of significant development, evidence has also demonstrated how significant foundational and transferable skills acquired from early childhood improve later work outcomes. Evidence suggests that high self-esteem is related to high social support, resilience, higher employability attributes (Dumont \& Provost, 1999; Fugate et al., 2004), and higher levels of selfefficacy that play a key role in translating education into employability (Quiring et al., 2017) with a higher likelihood of finding a job (Potgieter, 2012). Also, people's perception of their employment options and abilities influences employment chances (Rothwell \& Arnold, 2007). Therefore, there is a need to start early in adolescence and equip girls with the education and skills they need to obtain and retain quality employment (Verick, 2014).

The positive impact of engaging with mothers in the urban location (Delhi) reveals the potential that mothers have in supporting the aspirations of adolescent girls and in negotiating key life decisions. Future adolescent programs could leverage women's collectives by using feminist pedagogy to develop leadership among women who in turn create a safe space for adolescent girls' programs. This could also help shift gender relations within the household and other institutions by creating an inter-generational network of economically empowered change makers that can be sustained and scaled up through existing collectives under the National Rural Livelihood Mission (NRLM). NRLM has the mandate to partner across multiple sectors and address gender discrimination and promote school completion of girls. This policy provision can be leveraged for a multi-sectoral program to create an enabling 


\section{Impact of an Empowerment and Employability Program}

environment for adolescent girls. There is a need for studying the impact of intergenerational programming through women's collectives on adolescent girls' programs.

Similarly, in Jharkhand, the program's impact on school climate reinforces the need to create an enabling environment in schools for adolescent girls. Literature suggests that there is a need to bring gender equality on the agenda within the Indian school system (Edwards, 2017; Ramachandran, 2003). In Delhi, none of the intervention or comparison schools provide science as a subject stream for girls in Grades 11 and 12 but provide home science as a subject. This implies that the education in schools continues to be gendered and schools need to prepare boys to accept girls as equals and help both boys and girls to reimagine gender roles and expectations (Jain, 2003). School as an institution should not only provide education and training but also create a space that provides girls equal opportunities to aspire and plan to fulfil their aspirations. It should provide life-skills education and relevant information and linkages to higher education and training opportunities, thus supporting smooth school-to-work transition. While there are many studies in other countries on the impact of school climate on students' achievements, the lack of literature in India calls for similar studies in the Indian context, especially focusing on school-towork transition for adolescent girls.

\section{Limitations}

Although the findings are positive and promising, the limitations of the evaluation study also merit a brief discussion. Due to the limitations in process data, the program exposure or program dosage analysis was not feasible. The impact of the program at the school level was compared (control school vs. intervention school) assuming that all the students in the intervention schools received the program. The endline survey was conducted immediately after the conclusion of the program and therefore it is difficult to assert that the changes in outcome will sustain. Future studies should follow program participants for a longer period to understand their trajectories and long-term outcomes. It would be interesting to see whether the impact of the program sustains in the long run and whether it converts into school-to-work transition and positive life outcomes. For example, it would be interesting to see if high self-esteem and a positive gender attitude translate into continuation of studies, delaying of marriage or finding employment.

\section{References}

Achyut, P., Bhatla, N., Verma, H., Uttamacharya, S. G., Bhattacharya, S., \& Verma, R. (2016). Towards gender equality: The GEMS journey thus far. International Center for Research on Women. 
Journal of Youth Development | http://jyd.pitt.edu/ | Vol. 16 Issue 2-3 DOI 10.5195/jyd.2021.1048

Impact of an Empowerment and Employability Program

Allendorf, K. (2012). Women's agency and the quality of family relationships in India. Population Research and Policy Review, 31(2). 187-206. https://doi.org/10.1007/s11113-012-9228-7

Alvarado, G., Skinner, M., Plaut, D., Moss, C., Kapungu, C., and Reavley, N. (2017). A systematic review of positive youth development programs in low-and middle-income countries. YouthPower Learning, Making Cents International.

Betz, N. E., \& Luzzo, D. A. (1996). Career assessment and the career decision-making self-efficacy scale. Journal of Career Assessment, 4(4), 413-428.

Blum, R. W., Mmari, K., \& Moreau, C. (2017). It begins at 10: How gender expectations shape early adolescence around the world. Journal of Adolescent Health,61(4), S3-S4.

https://doi.org/10.1016/j.jadohealth.2017.07.009

Bonell, C., Dickson, K., Hinds, K., Melendez-Torres, G. J., Stansfield, C., Fletcher, A., Thomas, J., Lester, K., Oliver, E., Murphy, S., \& Campbell, R. (2016) The effects of positive youth development interventions on substance use, violence and inequalities: Systematic review of theories of change, processes and outcomes. NIHR Journals Library, 2016 May. PMID: 27253003.

Chohan, B. I., \& Khan, R. M. (2010). Impact of parental support on the academic performance and self concept of the student. Journal of Research and Reflections in Education, 4, 4-26.

https://www.researchgate.net/publication/216035869

Dalberg Advisors. (2020). DISHA impact evaluation: Key findings. IKEA Foundation and Author. https://ikeafoundation.org/wp-content/uploads/2021/04/March-31 -IKEA-Disha-Evaluation FinalReportDetailed.pdf

Dhar, D., Jain, T., \& Jayachandran, S. (2018). Reshaping adolescents' gender attitudes: Evidence from a schoolbased experiment in India (Working Paper No. 25331). National Bureau of Economic Research. https://www.nber.org/papers/w25331

Dulay, S., \& Karadağ, E. (2017). The effect of school climate on student achievement. In E. Karadağ (Ed.), The factors effecting student achievement (pp. 199-213).

https://www.researchgate.net/publication/317177284 The Effect of School Climate on Student Achieve $\underline{\text { ment }}$

Dumont, M., \& Provost, M. A. (1999). Resilience in adolescents: Protective role of social support, coping strategies, self-esteem, and social activities on experience of stress and depression. Journal of Youth and Adolescence, 28(3), 343-363. https://doi.org/10.1023/A:1021637011732

Durlak, J. A. (2009). How to select, calculate and interpret effect sizes. Journal of Pediatric Psychology,34(9), 917928. https://doi:10.1093/jpepsy/jsp004

Edwards, K. (2017). An analysis of the Indian further education system regarding gender inequality. https://www.eir.info/2017/01/13/an-analysis-of-the-indian-further-education-system-regarding-gender-inequality/ 
Franck, E., De Raedt, R., Barbez, C., \& Rosseel, Y. (2008). Psychometric properties of the Dutch Rosenberg selfesteem scale. Psychologica Belgica, 48(1), 25-35. http://doi.org/10.5334/pb-48-1-25

Fugate, M., Kinicki, A. J., \& Ashforth, B. E. (2004). Employability: A psycho-social construct, its dimensions and applications. Journal of Vocational Behaviour, 65(1), 14-38. http://doi.org/10.1016/j.jvb.2003.10.005

Hameed, N., \& Mehrotra, S. (2017). Positive youth development programs for mental health promotion in Indian youth: An underutilized pathway. International Journal of Community Medicine and Public Health, 4(10), 3488-3495. http://dx.doi.org/10.18203/2394-6040.ijcmph20174209

Hinson, L., Kapungu, C., Jessee, C., Skinner, M., Bardini, M., \& Evans-Whipp, T. (2016). Measuring positive youth development toolkit: A guide for implementers of youth programs. YouthPower Learning, Making Cents International.

Hunt, A., \& Samman, E. (2016). Women's economic empowerment: Navigating enablers and constraints. Overseas Development Institute (ODI). https://www.odi.org/sites/odi.org.uk/files/resource-documents/10683.pdf

Jain, S. (2003). Gender equality in education. Community based initiatives in India. Background paper prepared for Education for All Global Monitoring Report 2003/4. UNESCO.

Lara, L., \& Saracostti, M. (2019). Effect of parental involvement on children's academic achievement in Chile. Frontiers in Psychology. https://doi.org/10.3389/fpsyg.2019.01464

Lee, D. (2009). Training, wages, and sample selection: Estimating sharp bounds on treatment effects. Review of Economic Studies76(3), 1071-1102.

Lee, J. C., \& Mortimer, J. T. (2009). family socialization, economic self-efficacy, and the attainment of financial independence in early adulthood. Longitudinal and Life Course Studies, 1(1), 45-62.

Nanda, P., Gautam A., Verma, R., Khanna, A., Khan, N., Brahme, D., Boyle, S.,\& Kumar, S. (2014). Masculinity, intimate partner violence and son preference in India. International Center for Research on Women.

Nanda,P., Das, P., Singh, A., \& Negi, R. (2013). Addressing comprehensive needs of adolescent girls in India: A potential for creating livelihoods. International Center for Research on Women.

Pandita, R. (2015). Enrolment \& dropout percentage among boys \& girls up to secondary level in India: A comparative study. International Letters of Social and Humanistic Sciences, 49, 123-134.

Potgieter, I. (2012). The relationship between the self-esteem and employability attributes of postgraduate business management students. SA Journal of Human Resource Management,10(2), 419.

\section{http://doi:10.4102/sajhrm.v10i2.419}

Quiring S. Q., Boys, S. K., \& Harris, E. M. (2017). The role of self-efficacy in employability: Implications for pedagogical change. Thurgood Marshall Law Review,43(1),533-550.

Ramachandran, V. (2003). Gender and education for all: The leap to equality gender equality in education in India (Background paper prepared for the Education for All Global Monitoring Report 2003/4). UNESCO. 
Journal of Youth Development | http://jyd.pitt.edu/ | Vol. 16 Issue 2-3 DOI 10.5195/jyd.2021.1048

Impact of an Empowerment and Employability Program

Robins,R. W., Hendin, H. M., \& Trzesniewski, K. H. (2001). Measuring global self-esteem: construct validation of a single-item measure and the Rosenberg self-esteem scale. Personality and Social Psychology Bulletin,27(2), 151-161. https://doi.org/10.1177/0146167201272002

Rodríguez-Planas, N. (2012). Longer-term impacts of mentoring, educational services, and learning incentives:

Evidence from a randomized trial in the United States. American Economic Journal: Applied Economics, 4(4), 121-139. https://doi.org/10.1257/app.4.4.121

Rosenberg, M. (1965). Society and the adolescent self-image. Princeton University Press.

Rothwell, A., \& Arnold, J. (2007). Self-perceived employability: Development and validation of a scale. Personnel Review,36(1), 23-41. https://doi.org/10.1108/00483480710716704

Roy, S., Morton, M., \& Bhattacharya, S. (2018). Hidden human capital: Self-efficacy, aspirations and achievements of adolescent and young women in India. World Development, 111, 161-180.

https://doi.org/10.1016/j.worlddev.2018.07.002

Saravanakumar, P., \& Varakumari, J. E. (2019). A comparative study on women empowerment in urban and rural setting in Tamil Nadu. International Journal of Community Medicine and Public Health, 6(3), 1108-1111. https://doi.org/10.18203/2394-6040.ijcmph20190594

Schwarzer, R., \& Jerusalem, M. (1995). Generalized self-efficacy scale. In J. Weinman, S. Wright, \& M. Johnston (Eds.), Measures in health psychology: A user's portfolio. Causal and control beliefs (pp. 35-37). NFERNELSON

UNFPA \& Census of India. (2014). A profile of adolescents and youth in India. https://india.unfpa.org/en/publications/profile-adolescents-and-youth-india

UNICEF (2018). Guidance for the second decade: Programming with and for adolescents. https://www.unicef.org/media/57336/file

UNICEF \& Breakthrough. (2016). The adolescent empowerment toolkit. UN Children's Fund (UNICEF).

United Nations. (2018). World youth report: Youth and the 2030 agenda for sustainable development. https://www.un.org/development/desa/youth/wp-content/uploads/sites/21/2018/12/WorldYouthReport2030Agenda.pdf

United Nations, Department of Economic and Social Affairs. (2015, May). Population facts. https://www.un.org/esa/socdev/documents/youth/fact-sheets/YouthPOP.pdf

United Nations, Department of Economic and Social Affairs. (2019). World population prospects 2019: Highlights. http://bit.ly/2SgEZSs

Verick, S. (2014). Female labor force participation in developing countries. IZA World of Labor, 87, 1-10. https://doi.org/10.15185/izawol.87

Walker, J., Frediani, A. A., \& Trani, J. F.(2012). Gender, difference and urban change: implications for the promotion of well-being? Environment and Urbanization, 25(1),111-124.

https://doi.org/10.1177/0956247812468996 
Journal of Youth Development | http://jyd.pitt.edu/ | Vol. 16 Issue 2-3 DOI 10.5195/jyd.2021.1048

Impact of an Empowerment and Employability Program

World Bank (2014). Voice and Agency: Empowering women and girls for shared prosperity.

https://www.worldbank.org/content/dam/Worldbank/document/Gender/Voice and agency LOWRES.pdf

Yingling, M. C. L. (2019). Rock \& roll with it: Empowering girls to become leading womxn through music. https://Www.Academia.Edu/43350107/ROCK ROLL WITH IT EMPOWERING GIRLS TO BECOME LEADIN G WOMXN THROUGH MUSIC

Yu, C., Zuo, X., Blum, R. W., Tolman, D. L., Kågesten, A., Mmari, K., Meyer, S. D., Michielsen, K., Basu, C., Acharya, R., Lian, Q., \& Lou, C. (2017). Marching to a different drummer: A cross-cultural comparison of young adolescents who challenge gender norms. Journal of Adolescent Health, 61(4), S48-S54. https://doi.org/10.1016/j.jadohealth.2017.07.005 